\title{
家族が家庭で行った注意障害の行動観察評価
}

—BAAD (Behavioral Assessment of Attentioal Disturbance) の 有用性に関する検討一

\author{
豊倉 穣*1 菅原 敬*2 林 智美*2 \\ 西村葉子 $* 2$ 村山理恵 $* 2$
}

\section{Inattention Behavioral Assessment conducted by the Family at Home : Validity of BAAD（Behavioral Assessment of Attentional Disturbance)}

\author{
Minoru Toyokura, ${ }^{* 1}$ Takashi Sugawara, ${ }^{* 2}$ Tomomi Hayashi, ${ }^{* 2}$ \\ Youko Nishimura, ${ }^{* 2}$ Rie Murayama ${ }^{* 2}$
}

\begin{abstract}
Attentional disturbance following brain damage is usually evaluated by several neuropsychological tests. In a rehabilitation setting, however, the primary concern is not task performance, but rather functional real-world behavior. To address this requirement, a new assessment system for attentional behavior, BAAD (Behavioral Assessment of Attentional Disturbance), has been developed. This assessment is generally completed by the patient's therapist (occupational therapist, OT) during therapy. The aim of this study was to investigate whether BAAD completed by the family at home (BAAD-FM) yields results that are comparable to BAAD completed by an OT during occupational therapy (BAAD-OT). The subjects were 53 patients with brain damage. $\mathrm{BAAD}$ consists of six items thought to be associated with attentional behaviors. Each item is rated (0 to 3) based on the frequency with which the problem behaviors appeared during daily living at home and daily sessions of occupational therapy. The intraclass-correlation coefficient of the total score between BAAD-FM and BAAD-OT was 0.89 . The mean (SD) values of the total scores were 3.7 (3.7) and 3.7 (3.6), respectively. Similarly, there were no significant differences in any of the item scores between BAAD-FM and BAAD-OT. The coincidence rate between the two BAAD tests on an item-by-item basis was over $64 \%$ for all items but one $(43 \%)$. In conclusion, the total BAAD-FM score seemed comparable to the total BAAD-OT score and valuable for detecting attentional disturbance. (Jpn J Rehabil Med 2009 ; 46:306-311)
\end{abstract}

要 旨：近年考案された注意障害の行動評価尺度 (BAAD, Behavioral Assessment of Attentional Disturbance）は，原則的に作業療法施行中の場面を作業療法士（OT）が観察して スコア化する。今回，家庭での家族による評価を実施し，注意障害の評価に有用か検討した。 脳障害者（脳卒中，脳外傷など） 53 名を対象とした。OT，家族による評価合計点（最高 18 点） はほぼ一致し，級内相関係数も 0.89 と高值を示した。項目別に検討すると， 6 個中 5 項目では $64 \%$ 以上で両検者のスコアが完全に一致したが，1 項目のみ $43 \% に$ 留まった。以上より家庭 での評価も「注意」障害の検出に有用と考えられた。

Key words : 高次脳機能障害 (higher cortical function), 注意障害 (attentional deficit), 行動 評価 (behavioral assessment), リハビリテーション (rehabilitation)

2009 年 1 月 14 日受付, 2009 年 3 月 30 日受理

*1 東海大学医学部付属大磯病院リハビリテーション科, *2リハビリテーション室/ $7259-0198$ 神奈川県中郡大磯町月京 21-1 Department of Rehabilitation Medicine, ${ }^{* 1}$ Division of Rehabilitation Medicine, ${ }^{* 2}$ Tokai University Oiso Hospital E-mail : toyokura@juno.dti.ne.jp 


\section{はじめに}

注意障害は脳損傷後の高次脳機能障害としてしばし ば患者の quality of life（QOL）を阻害する。評価には

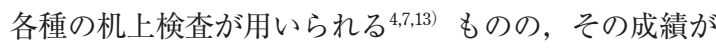
注意障害による問題行動と直観的に結びつきにくい8). この問題を解決するために，日常生活上の行動観察に 基づいた評価尺度が報告されている ${ }^{1,6,8,9,14)}$ 。著者ら も, 注意障害に関連する諸行動をその出現頻度から評 価する行動評価尺度 Behavioral Assessment of Attentional Disturbance（以下 BAAD）を開発した ${ }^{10)}$ (図 1).

注意障害の行動評価は, 医学的知識のあるリハビリ テーション（以下，リハ）スタッフによるのが望まし いという Ponsford ( $^{8)}$ の提言に従い, BAAD も作業療 法士 (occupational therapist：OT) による評価を原則 とした。しかし, 家庭内での日常行動からもしばしば 注意障害に関する所見が得られる。検者や観察環境に 依存しない検查結果の再現性が確認できれば，病院内 から家庭あるいはその逆の一貫した継続評価も可能と なる。そこで注意障害を家庭生活の観察に基づいた $\mathrm{BAAD}$ で評価し，その結果を本来の作業療法士による 評価結果と比較した。そその上で, 家族による家庭での $\mathrm{BAAD}$ 評価の意義, 限界を検討した.

\section{対象と方法}

リ八科に入院または外来通院中で何らかの脳障害を 有する症例のうち作業療法施行中の患者を無作為に 53 名 (19 96 歳, 平均 58歳, 男性 33 名, 女性 20 名) 抽出して対象とした。エントリーの条件として運動障 害やADLの状況には制約を設けなかったが，Glasgow Coma Scale (GCS) は 15 点の症例とした。発症 からの期間は平均 387 日, 中央值 197 日であった。こ のうち 21 名が入院患者, 32 名が外来患者で, 各臨床 診断の内訳は脳梗塞 23 名, 脳出血 14 名, くも膜下出 血 8 名, 脳外傷 4 名, 脳腫瘍 2 名, 脳動脈瘤術後, 脳 炎が 1 名ずつとなった。

注意障害は作業療法実施中の様子を OTが，また家 庭での日常行動を家族が観察し, BAAD で評価した。 作業療法課題は通常の内容とし, 本評価に関して特別 の変更はしなかった。作業療法時の観察は 2,3 日の 訓練経過で判断した.

入院患者の家庭内観察は外泊時に実施した。外来患 者を含め，最も長く患者と一緒に時間を過ごす家族に 十分説明して BAAD の評価を依頼した。

$\mathrm{BAAD}$ は 6 項目からなり, 各問題行動の出現頻度か ら $0 \sim 3$ の点数を付与する (図 1). 合計点を算出 $(0$ ～ 18 点）するが，高点数ほど重症である．両評価場面 での BAAD スコアを合計点および観察項目ごとに比

\begin{tabular}{ll}
\hline 観察すべき問題行動 & 評価 \\
\hline 1. 活気がなく, ボーっとしている。 & $0,1,2,3$ \\
2. 訓練(動作)中, じっとしていられない, 多動で落ち着きがない。 & $0,1,2,3$ \\
3. 訓練(動作)に集中できず, 容易に他のものに注意がそれる。 & $0,1,2,3$ \\
4. 動作のスビードが遅い。 & $0,1,2,3$ \\
5. 同じことを2回以上指摘されたり, 同じ誤りを2回以上することがある。 & $0,1,2,3$ \\
6. 動作の安全性への配慮が不足, 安全確保が出来ていないのに動作を開始する。 & $0,1,2,3$ \\
\hline
\end{tabular}

\begin{tabular}{l}
\hline 評価点:問題行動の出現頻度を4段階で重み付け \\
0: 全くみられない \\
1: 時にみられる(観察される頻度としては1/2未満, 観察されない方が多い) \\
2: しばしばみられる(観察される頻度としては1/2以上, 観察される方が多い) \\
3: いつもみられる(毎日·毎回みられる) \\
\hline
\end{tabular}

合計点 $\quad / 18$

図 1 BAAD（Behavioral Assessment for Attentional Disturbance）の内容と採点 $\mathrm{BAAD}$ では各項目の行動が出現した頻度で $0 \sim 3$ の評価点を付与し, 合計点を求める. 採点の指標は図 に示すとおりである。本研究における OT 場面の評価は院内での OT 訓練中の，家庭場面での評価は通 常の家庭生活における行動観察による. 
較した。統計手法としては級内相関係数，Wilcoxon の符号付順位検定を用いた。また分類されたデー夕に 対して, その分類項目の独立性は $\chi^{2}$ 検定（期待度数 が 5 以下のセルがある場合は Fisher の直接確率計算 法）で分析した.

\section{結果}

OTによるリ八訓練場面での評価（以下，OT 場面 とする）拈よび家族による家庭での評価（以下，家庭 場面とする）に基づく $\mathrm{BAAD}$ 合計点はそれぞれ 0 〜 16， $0 \sim 18$ 点に分布した. OT 場面，家庭場面で 0 点 すなわち注意障害なしと判断されたのは 13 および 12 名であった。後者の 12 名のうち，6 名は OT 場面で も 0 点，また残り 6 名のうち 3 名が 1 点と判定されてい た。雨場面での合計点の平均（標準偏差）值は 3.7 (3.6), 3.7 （3.7）とほぼ一致した. 53 名のうち 33 名（62\%） で両者の得点差が1以内（完全一致を含む）であった. $\mathrm{BAAD}$ 評価合計点の分布を図 2 に示す．級内相関係数 は $0.89 （ p=0.0001 ）$ を呈した。

53 名における各項目粗点の最小值, 最大值は OT 場面，家庭場面ともに全て 0 点， 3 点であった．表に 各点数を両評価場面で比較した結果を示す．両者の級 内相関係数は 1 項目を除いて $0.645 \sim 0.84$ と 0.6 を超

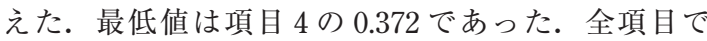
OT場面，家庭場面のスコアに有意差を認めなかっ
た. 症例は項目 1 〜 6でそれぞれ両者のスコアが完全 に一致したのは $43.4 〜 81.1 \%$ あった。ここでも項 目 4 が $43.4 \%$ と最低值を呈した。本項目では，OT， 家族の評価が一致しなかった 30 名中 OT の評価点の 方が高かったもの12名，低かったもの18名となった。

項目 4 は動作のスピードに関する観察であり，運動 障害との関連を検討するため麻痺の有無（程度は問わ ず）と評価スコアの関係を分析した（図 3)。OT場面， 家庭場面とも注意障害の有無と麻痺の有無に一貫した 傾向はみられなかった（ $\chi^{2}$ 検定，それぞれ $p=0.399$, 0.889)。また両場面で評価スコアが一致しなかった 30 例において，点数の高低と麻疩の有無との関連を分析 したが両者に明らかな傾向はみられなかった（Fisher の直接確率計算法, $p=1.00)$.

表 項目ごとにみた $\mathrm{BAAD}$ 評価点の比較：OT 場面, 家庭場面

\begin{tabular}{cccc}
\hline 項目 & $\begin{array}{c}\text { 級内相関係数 } \\
(p)\end{array}$ & $\begin{array}{c}\text { 有意差 } \\
(p)^{*}\end{array}$ & $\begin{array}{c}\text { 完全に一致し } \\
\text { た割合 }(\%)\end{array}$ \\
\hline 1 & $0.663(0.0001)$ & 0.481 & 52.8 \\
2 & $0.813(0.0001)$ & 0.166 & 81.1 \\
3 & $0.645(0.0001)$ & 0.393 & 71.7 \\
4 & $0.372(0.048)$ & 0.169 & 43.4 \\
5 & $0.704(0.0001)$ & 0.257 & 60.4 \\
6 & $0.840(0.0001)$ & 1.000 & 64.2 \\
\hline
\end{tabular}

*Wilcoxon の符号付き順位検定

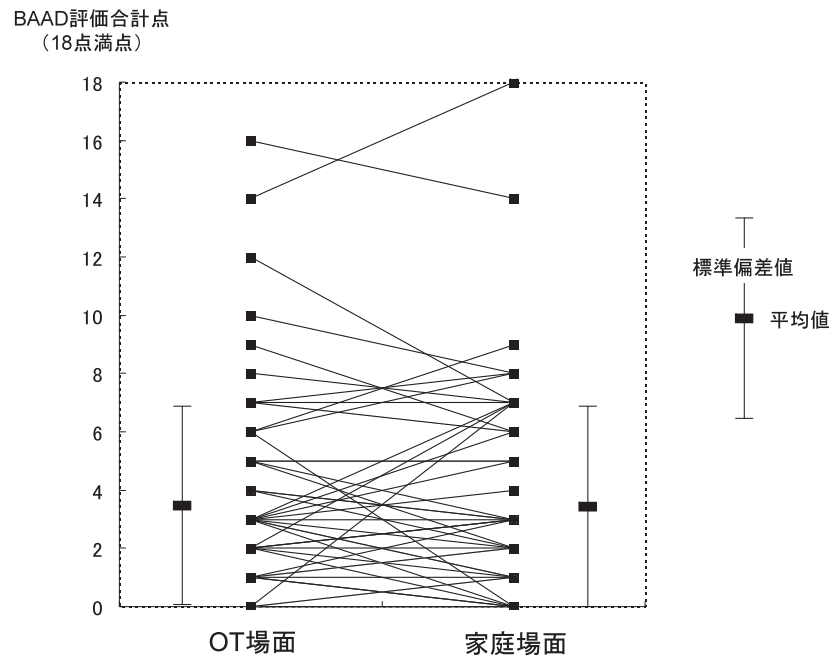

図 2 OT 場面，家庭場面の BAAD 評価点（合計点） 同一症例を線で結んである。評価合計点は全域に分布するが，傾向 として低い点数を呈する症例が多い。両評価場面における平均值, 標準偏差值も合わせて示す。 


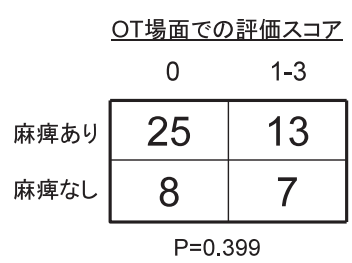

a

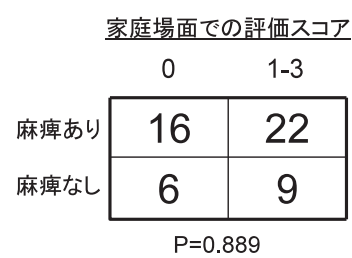

b

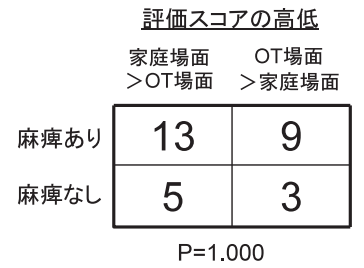

C

図 3 麻痺の有無と評価スコアの関連性（項目 4) 麻痺の有無と注意障害の有無との関係を a (OT 場面), b (家庭場面) に示す。統計には $\chi^{2}$ 検定を用いた。両評価場面でスコアが一致しなかった 30 例に対して，評価スコアの高低と麻 痺の有無との関係を $\mathrm{c}$ に示す。統計には Fisherの直接確率計算法を用いた. いずれも $(\mathrm{a} \sim \mathrm{c})$ 分類項目間に一定の傾向はみられなかった.

\section{考察}

脳損傷後の注意障害を評価する手段として，患者の 行動観察による方法はごくわずか報告されているに過 ぎない. Ponsford らの Rating Scale of Attentional Behaviour $(\mathrm{RSAB})^{8)}$, Whyte $の$ Moss Attention Rating Scale (MARS $)^{14)}$ は妥当性や信頼性が検討されている ものの，世界的に普及した評価ツールには至っていな い. 先崎ら ${ }^{9)}$ は RSAB の日本語訳を試み，妥当性， 信頼性を検討しているが，本邦で独自に開発された評 価手段はない，著者らも当初は RSAB を日本語訳して 用いてみた。しかし，評価点を与える出現頻度の設定 が 5 段階と多くその判定区分が明確でない，「知的精 神課題が遅い」という観察項目では具体性や判断基準 に乏しい，「容易に注意が他に逸脱する」と「2つ以 上のものに同時に注意を向けられない」の 2 項目は厳 密に分けられないことがあるなど，いくつかの問題が みられた。そこでこれらに配慮した新たな評価手段も 必要と考え，BAADを開発したものである ${ }^{10)}$. 作成に あたってはRSAB の観察項目や判定手続きを参考にし たため，内容の一部が類似したものとなっている．脳 障害者への使用を通して検討した $\mathrm{BAAD}$ の妥当性, 信頼性はすでに報告した ${ }^{10)}$ 。これらはいずれも「注 意」障害に関する問題行動の自然な出現をチェックす るものである．観察された出現頻度で評価点を与え， 合計点を算出する。 RSAB は 14 項目，MARS は 53 項 目で構成される. BAAD には当初 12 項目を設けたが, その後の因子分析によって各因子への重み付けがそし く，また特異的でない項目を削除した。 その結果，最 終的には 6 項目の評価チャートとなった ${ }^{10)}$. 詳細は後 述するが，BAAD の特徵として RSAB より検者間の信
頼性が高いことが示唆されている.

各評価の観察は RSAB, MARS とも理学療法士 (physical therapist：PT) や OTなどのリハスタッフ が行う．理論的には，家庭で家族が行うことも患者自 身が自己報告することも可能である，しかし，障害の 自己認識がしばしば損なわれること，家族は入院患者 の問題行動に触れる機会が少ないこと，期待や希望が 加味されたバイアスがはいりやすいこと，などの問題 が指摘されている8,14). 注意に関する行動は背景要因 が多彩なうえ, 変動し易い。この点, 高次脳機能障害 に知識のあるリハスタッフのほうが的確に評価ができ ると考えられている. BAADもこれらに配慮して OT がリハ訓練場面の観察をもとに評価することとした.

しかし，家庭生活の場面で注意障害による問題行動 が観察されることも少なくない. 行動評価という意味 ではその方がより生活上のハンディに直結し易い。広 く高次脳機能障害の評価という視点では, 遂行機能障 害の質問表 $(\mathrm{DEX})^{2)}$ ，リバーミード行動記憶検査に付 属する生活健忘チェックリスト ${ }^{12)}$, 脳外傷の認知一行 動障害尺度 ${ }^{5)}$ など家族の観察を前提とした行動評価 も行われている。そこで本研究ではあえて BAADに 対する家族の評価を吟味したものである.

その結果，OT 場面と家庭場面による評価合計点は ほぼ一致し，級内相関係数も高值を示した。つまり $\mathrm{BAAD}$ は良好な検者間信頼性を有し，OT 場面に限定 せず家庭での行動観察からも注意障害に関して有用な 情報が得られることを示唆している.

RSAB では言語聴覚士（speech therapist：ST） と OT 間での検者間信頼性が検討されているものの，両 者の相関係数は $0.508 〜 0.561$ と概して低值を示した ${ }^{8)}$. 評価総点にも若干のずれがあり，STがやや高い值で 
あった.PT と OTで比較した MARS の場合も検者の 違いが評価点に影響し，OTの方が注意機能を低く評 価する傾向を示した ${ }^{14)}$ 。これらの乘離には判定者の職 種に加えて評価環境の違いも影響したと考えられてい る. BAADにおいて既に吟味した結果では，評価点の 級内相関係数は OT 対 PT，OT 対 ST でそれぞれ 0.84 , 0.79 と比較的よい值を示した ${ }^{10,11)}$.この点, $\mathrm{BAAD} の$ 本質として検者や評価環境に比較的影響を受けにくい 傾向が示唆された。今回は同じ医療職どうしの比較で ないため，より厳しい条件下で検者間の再現性を検討 したものといえる。しかしながら，総点数には高い信 頼性が得られた。その背景にはいくつかの要因が考え られる。

因子分析の結果から，BAAD は高次の複雑な情報処 理に関連した機能ではなく，低次の注意機能を反映す るものと考えられている ${ }^{10)}$. 高次の情報処理ほどその 背景にある認知機能も複雑となり，行為や行動の観察 から注意機能の関与を見極めるのに専門知識が必要と なる，評価環境の差異による影響も大きくなりがちで ある。しかし，BAAD は低次で単純な行為の観察に基 づくため，医学的知識の有無や評価環境に影響を受け にくかった可能性がある。なお，BAAD の開発にあ たっては，評価項目の記載もなるべく具体的で平易な 表現にし，検者の判断に迷いやバイアスが生じにくい ように配慮してある。

さて，検者間の再現性は対象とした患者群の特性に よっても影響を受ける。最重度の症例，逆に全く注意 に問題のない症例では誰がどこで評価しようがそれぞ れ高点数，低点数が付与されやすい．計算上は高い信 頼性を示唆する統計值が得られてしまう。この点，今 回の対象者の $\mathrm{BAAD}$ 総点はほぼ得点範囲の全域に分 布しており，著しい偏りはみられていない。ただし平 均值が 3.7 であることを考慮すると，重症例が少な かった傾向は否めない。この場合， $\mathrm{BAAD}$ の感度が低 くなる傾向があることは既に述べた。これらの要因が 両群間の有意差を減じる方向に影響した可能性も否定 できず，さらなる検討も必要かと思われた。

個々の項目についても両者の評価は概ね一致してい た。桑原らは「良好」「普通」「可能」と判断される信 頼性の基準としてそれぞれ 0.8，0.7，0.6 以上の級内 相関係数值を挙げている ${ }^{3)}$. 今回の分析では項目 4 の みが 0.6 に満たず，スコアの一致率も最低值を示した. ただ，スコアの乘離に（「家族は高点数をつけやすい」
など）一定の傾向はなく，OT，家族の平均值に有意 差はみられなかった。この項目 4 は「動作のスピード が遅い」という内容である. 情報処理速度の遅鈍化を 反映した行動に着目したものだが，他の項目と比べて 普遍的な判断基準が設定しにくい欠点がある。また， 家族は過去の患者の有り様を知っているので，必然的 に「以前より動作がスローになったか」という視点で 評価する。これに対して OTは，臨床的に一般的，常 識的な「基準」に照らし合わせて患者の行動を判定す る.一方は個人内で対比した能力の変化，他方はある 外的基準と個人パフォーマンスの比較である。これら の評価視点やその判断プロセスの相違が評価結果にば らつきを来たしたものと思われた。この考えは両者の 評価点の大小に一定の傾向がなかったことにも矛盾し ない。

項目 4 についてはその内容から運動障害との関連性 も吟味した，家族の評価では，運動障害による緩慢な 動作が注意障害によるものと判断されてしてしまう可 能性が危惧されたからである。しかし，注意障害の有 無と麻痺の有無とに明らかな関連はみられなかった。 OT場面についても同様の結果が得られた。さらに, 両評価場面の点数が乘離する場合も，その高低の違い は麻疩の有無に影響されず先の結果を支持する結果と なった。

BAAD は OT，家族間の評価にも信頼性を有するが， 一部の項目を再吟味し評価の一致度を高めることでさ らに信頼性が向上できる可能性も否定できない。これ については今後の検討が必要である.

\section{文献}

1) Hart T, Whyte J, Millis S, Bode R, Malec JF, Richardson $\mathrm{RN}$, Hammond F : Dimensions of disordered attention in traumatic brain injury : further validation of the Moss Attention Rating Scale. Arch Phys Med Rehabil 2006 ; 87 : 647-655

2）鹿島晴雄（監訳）：BADS遂行機能障害症候群の行動評 価 日本版 質問表. 新興医学出版, 東京, 2003

3）桑原洋一, 斉藤俊弘, 稲垣義明 : 検者内および検者間の Reliability（再現性, 信頼性）の検討. 呼吸と循環 1993 ; $41: 945-952$

4) 高次脳機能障害学会 : 標準注意検査法・標準意欲評価 法. 新興医学出版, 東京, 2006

5）久保義郎, 長尾初瀬, 小崎賢明, 加藤礼子, 中村憲一, 塩 沢哲夫, 下平耕司, 中元洋介, 橋本圭司 : 脳外傷者の認 知一行動障害尺度 (TBI-31) の作成一生活場面の観察に よる評価. 総合リハビリテーション $2007 ; 35$ : 921-928

6) Levin HS, High WM, Goethe KE, Sisson RA, Overall JE, 
Rhoades HM, Eisenberg HM, Kalisky Z, Gary HE : The neurobehavioural rating scale : assessment of the behavioural sequelae of head injury by the clinician. J Neurol Neurosurg Psychiatry 1987 ; 50 : 183-193

7) Lezak MD, Howieson DB, Loring DW (eds) : Neuropsychological Assessment. 4th Ed, Oxford University Press, Oxford, 2004

8) Ponsford J, Kinsella G : The use of a rating scale of attention behaviour. Neuropsychol Rehabil 1991 ; 1 : 241-257

9) 先崎 章, 枝久保達夫, 星 克司, 加藤元一郎, 三村 將, 水野雅文, 鹿島晴雄 : 臨床的注意スケールの信頼性と妥 当性の検討. 総合リハビリテーション 1997 ; 25 : 567-573

10) Toyokura M, Yamashita K, Hayashi T, Nishimura Y, Sawatari M, Kikui R, Akutsu I, Tanno K, Ohtsuka M, Wada $\mathrm{N}$ : A newly developed assessment scale for attentional disturbance based on behavioral problems ; Behavioral
Assessment of Attentional Disturbance (BAAD). Tokai J Exp Clin Med 2006 ; 31 : 29-33

11）豊倉 穣 :「注意」障害に関する行動評価（BAAD）完 成版の検討 $2:$ 検者内, 検者間信頼性.リハビリテー ション医学 $2006 ; 43$ (Suppl): S233

12）綿森淑子, 原 寛美, 宮森孝史, 江藤文夫 : 日本版リバー ミード行動記憶検査. 千葉テストセンター, 2002

13) Whyte J, Hart T, Laborde A, Rosenthal M : Rehabilitation of the patient with traumatic brain injury. In Rehabilitation Medicine (ed by DeLisa JA, Gans BM). Lippincott-Raven, Philadelphia, 2000 ; pp 1191-1240

14) Whyte J, Hart T, Bode R K, Malec JF : The Moss Attention Rating Scale (MARS) for traumatic brain injury : initial psychometric assessment. Arch Phys Med Rehabil $2003 ; 84: 268-276$ 